\title{
THE CONFUSING TAXONOMY AND NOMENCLATURE OF SYZYGIUM CONFUSUM COMPLEX (MYRTACEAE)
}

Received June 02, 2021; accepted August 02, 2021

\section{PUDJI WIDODO}

Fakultas Biologi, Universitas Jenderal Soedirman. Jln. Dr. Soeparno 63, Purwokerto 53122, Indonesia. Biology Department, Institut Pertanian Bogor (IPB University), Jln. Raya Dramaga, Kampus IPB, Dramaga, Bogor 16680, Indonesia.Email: pwidodo@unsoed.ac.id

\section{JAN FRITS VELDKAMP (†)}

Naturalis Biodiversity Center, Research Group of Tropical Botany, P.O. Box 9517, 2300 RA Leiden, the Netherlands. Institute of Biology Leiden, Leiden University, P.O. Box 9505, 2300 RA Leiden, the Netherlands.

\begin{abstract}
WIDODO, P. \& VELDKAMP, J. F. 2021. The confusing taxonomy and nomenclature of Syzygiun confusum complex (Myrtaceae). Reinwardtia 20(2): 43-49. - The taxonomic and nomenclatural confusions surrounding the Syzygium confusum complex are elucidated. For that purpose, type specimens are designated and circumscriptions are presented for each species. Typifications, newly characterized descriptions and illustrations are presented for Syzygium korthalsii Widodo, S. confusum (Blume) Bakh.f., S. blumei (Steudel) Merr. \& L.M.Perry, S. insigne (Blume) Merr. \& L.M.Perry. The new species Syzygium sipirokense Widodo \& Veldkamp is described.
\end{abstract}

Key words: Jambosa, Malesia, Myrtaceae, Southeast Asia, Syzygium.

\begin{abstract}
ABSTRAK
WIDODO, P. \& VELDKAMP, J. F. 2020. Kekusutan taksonomi dan tata nama kompleks Syzygium confusum (Myrtaceae). Reinwardtia 20(2): 43-49. - Kekusutan taksonomi dan tata nama jenis seputar kompleks Syzygium confusum dicoba diuraikan dengan pemantapan penunjukan spesimen-spesimen tipenya. Selanjutnya perapian batasan takson yang termasuk jenis kompleks juga telah dilakukan. Oleh karena itu pemantapan nama dan pertelaan serta ilustrasi Syzygium korthalsii Widodo, S. confusum (Blume) Bakh.f., S. blumei (Steudel) Merr. \& L.M.Perry, S. insigne (Blume) Merr. \& L.M.Perry dan jenis baru Syzygium sipirokense Widodo \& Veldkamp disajikan.
\end{abstract}

Kata kunci: Asia Tenggara, Jambosa, Malesia, Myrtaceae, Syzygium.

\section{INTRODUCTION}

In studying the Sumatran free petalled species of Syzygium one may have difficulty in identifying the species with narrow leaves, especially because some of their representatives are rare and hence poorly known (Backer \& Bakhuizen van den Brink Jr., 1963:343). In April 1972, for the Flora Malesiana project, Bakhuizen van den Brink Jr. \& van Steenis tentatively identified and annotated two specimens preserved in L (namely HLB no. 898.203-342 part of Herb Blume s.n. collected in Java without definite locality and HLB no. 898.203-344 collected around Bogor, Java by an unknown collector) as Syzygium confusum (Blume) Bakh.f. Another specimen (HLB no 898.203-345 collected in Mount Malintang, West Sumatra by Korthals) was tentatively identified by them as Syzygium cf. confusum (Blume) Bakh.f.

In 1846 Korthals had already identified his collection (HLB 898.203-345) as Jambosa lanceolata Korthals. Confusion arose when Blume
(1849) proposed the name Jambosa confusa Blume for other material from Java and Sumatra, inferring that Korthals's name was superfluous, as Jambosa lanceolaria was an earlier name for Korthals's material, based on Eugenia lanceolaria Roxb. (1832). To rectify this, Blume (1850) proposed Jambosa korthalsii Blume as a new name for Jambosa lanceolata Korthals. Although these specific epithets are similar, they do not mean exactly the same thing because lanceolarius (= small tip of a spear) and lanceolatus (= lancetshaped) and they are not confusable under the ICNafp (Turland et al., 2018). In this case, what is the nomenclatural status of Blume's proposed new name Jambosa korthalsii Blume? Is it a superfluous name? Korthals' specific epithet lanceolatum cannot be transferred to Syzygium because it is pre -empted by the combination $S$. lanceolatum (Lam.) Wight \& Arn. (1834). It is clear, therefore, that there is a need to clarify this nomenclaturally confused situation. 
In revising the taxonomy of the narrow leaves Syzygium in Sumatra (Widodo, 2011) we found that twigs, leaf shape, leaf base and apex more often than not offer valuable characters for deli miting species. Consequently, morphological variation in these characters in the Syzygium confusum complex will be given special attention.

During the course of this study, in BO we found specimens from Sumatra with characteristics very much like Syzygium insigne (Blume) Merr. \& L.M.Perry and S. blumei (Steudel) Merr. \& L.M.Perry (species also related to the Syzygium confusum complex) but with consistently varying characteristics. We take this opportunity to describe these specimens and propose a species new to science.

\section{MATERIALS AND METHODS}

Materials used in this research are herbarium specimens from Sumatra, Java, and Borneo preserved in the herbaria of $\mathrm{BO}, \mathrm{L}$ and $\mathrm{K}$. Procedures and methods of observations used in this study mostly followed those elaborated by Rifai (1976), de Vogel (1987), Widodo (2011) and Widodo (2012).

\section{RESULTS AND DISCUSSION}

Results of our renewed observations of morphological characters of Syzygium confusum complex are presented in Table 1. We found that combinations of these characters are of assistance for delimiting closely related species as can be observed in Table 1.

1. SYZYGIUM KORTHALSII Widodo. - Fig. 1. Jambosa lanceolata Korth. Ned. Kruidk. Arch. 1: 199. 1846. [non Syzygium lanceolatum (Lam.) Wight \& Arn., 1834]. - Jambosa korthalsii Blume, Mus. Bot. Lugd.-Bat. 1: 101. 1849 [1850], nom. superfl. - Syzygium korthalsii Widodo, Reinw. 13(3): 235-240 (2012). - TYPE: INDONESIA, West Sumatra, Gunung Malintang, Korthals s.n. (Holotype L! HLB no. 898.203345), designated by Widodo (2012).

Tree diameter unknown. Twigs usually 4-angled to 4-winged, with smooth and whitish pale brown bark. Leaves relatively long compared to width, the leaf form very narrowly ovate, $30-45 \mathrm{~cm}$ by $2.5-5 \mathrm{~cm}$, brown above and milky brown below when dry; leaf base cordate, leaf apex long narrowly acuminate; petiole ca. $3 \mathrm{~mm}$ long, swollen and corky, drying pale brown; midrib channelled on the upper surface and raised on the lower surface, pale brown when dry; major lateral veins consists of $\mathrm{ca}$. 25 pairs, $1-1.5 \mathrm{~cm}$ apart, at an angle of $60^{\circ}-70^{\circ}$, sometimes curved near the midrib and straight near the intramarginal veins; minor lateral veins absent or present, oil dots between 2 major lateral veins less than 20 per $\mathrm{cm}^{2}$; intramarginal vein 1 or 2 , faint, $1-3 \mathrm{~mm}$ from margin. Inflorescence a terminal cyme, but the flower with a pseudostipe 5-7 $\mathrm{mm}$ long, hypanthial cup funnel-shaped; sepals triangular, 5-6 mm long, $5 \mathrm{~mm}$ wide; petals unknown; style $35 \mathrm{~mm}$ long. Fruits unknown.

Distribution. Syzygium korthalsii is known from a limited area in West Sumatra, namely in Pariaman and in Gunung Malintang.

Notes. Syzygium korthalsii can be readily distinguished from other Sumatran species by its leaf form which is very narrowly ovate and almost linear, reaching approximately $45 \mathrm{~cm}$ long and only around $3.5 \mathrm{~cm}$ wide on average.

\section{SYZYGIUM CONFUSUM (Blume) Bakh.f. -} - Fig. 2.

Jambosa confusa Blume, Mus. Bot. Lugd.-Bat. 1: 101. 1849 (non $J$. confusa Blume ex Miq., Anal. Bot. Ind. 1: 27. 1850, nom. inval., in syn. sub $E$. microbotrya Miq., non pert.). Syzygium confusum (Blume) Bakh.f. in Bakhuizen v/d Brink Jr. \& Koster, Blumea 12: 61. 1963. - Eugenia dolichophylla Koord. \& Valeton, Meded. Lands Plantentuin 40: 78. 1900, "doligophylla" non Eugenia dolichophylla Kiaersk., En. Myrt. Bras. 157. 1893, nec Syzygium dolichophyllum (Laut. \& K.Schum.) Merr. \& L.M.Perry, J. Arn. Arb. 23: 249. 1942.Eugenia malayana Gagnep. in Lecomte, Fl. IndoChina 2: 838. 1921. Syzygium malayanum (Gagnep.) I.M.Turner, Gard. Bull. Singapore 47: 378. Jul 1997 ("Dec 1995”); Singapore Natl. Acad. Sci. 22-24: 21. Aug 1997 ("1996”), nom. superfl. - Syzygium amshoffianum Merr., Philipp. J. Sci. 79: 366. 1951 ("1950”), nom. superfl. - TYPE: INDONESIA, Java without definite locality. Herb. Blume s.n. (Holotype L! HLB no. 898.203-342), tentatively identified/annotated as Syzygium confusum (Blume) Bakh.f. in April 1972 by Bakhuizen van den Brink Jr. \& van Steenis.

Tree to $8 \mathrm{~m}$ tall. Twigs terete and slightly compressed near the nodes. Leaves narrowly lanceolate, $20-30 \mathrm{~cm}$ by $3-5 \mathrm{~cm}$ tapered gradually from the middle to apex; upper surface blackish brown, lower surface reddish brown when dry; leaf base 
Table 1. Morphological differences between species of Syzygium confusum complex

\begin{tabular}{|c|c|c|c|c|c|c|}
\hline No & Character & S. korthalsii & S. confusum & S. blumei & S. insigne & S. sipirokense \\
\hline 1 & Twigs & $\begin{array}{l}\text { 4-angled to } 4- \\
\text { winged }\end{array}$ & $\begin{array}{l}\text { Terete and slightly } \\
\text { compressed near } \\
\text { nodes }\end{array}$ & Terete & $\begin{array}{l}\text { Terete and 4- } \\
\text { angled near } \\
\text { nodes }\end{array}$ & 4-winged \\
\hline 2 & Leaf form & $\begin{array}{l}\text { Very narrowly } \\
\text { ovate }\end{array}$ & $\begin{array}{l}\text { Narrowly lanceo- } \\
\text { late }\end{array}$ & $\begin{array}{l}\text { Quite nar- } \\
\text { rowly ovate }\end{array}$ & $\begin{array}{l}\text { Narrowly } \\
\text { ovate }\end{array}$ & $\begin{array}{l}\text { Quite narrowly } \\
\text { ovate to almost } \\
\text { oblong ovate }\end{array}$ \\
\hline 3 & Leaf apex & $\begin{array}{l}\text { Long nar- } \\
\text { rowly acumi- } \\
\text { nate }\end{array}$ & Acute to acuminate & $\begin{array}{l}\text { Acute to acu- } \\
\text { minate }\end{array}$ & Acute & $\begin{array}{l}\text { Acuminate to api- } \\
\text { culate }\end{array}$ \\
\hline 4 & Leaf size & $\begin{array}{l}30-45 \mathrm{~cm} \text { by } \\
2.5-5 \mathrm{~cm}\end{array}$ & $\begin{array}{l}20-44 \mathrm{~cm} \text { by } 3-5 \\
\mathrm{~cm}\end{array}$ & $\begin{array}{l}15-20 \mathrm{~cm} \text { by } \\
2-3 \mathrm{~cm}\end{array}$ & $\begin{array}{l}4-10 \mathrm{~cm} \text { by } 1- \\
2.75 \mathrm{~cm}\end{array}$ & $\begin{array}{l}10-15 \mathrm{~cm} \text { by } 3- \\
5.5 \mathrm{~cm}\end{array}$ \\
\hline 5 & Leaf base & cordate & $\begin{array}{l}\text { Almost narrowly } \\
\text { cuneate }\end{array}$ & $\begin{array}{l}\text { Rounded or } \\
\text { subcordate }\end{array}$ & $\begin{array}{l}\text { Subcordate or } \\
\text { almost } \\
\text { rounded }\end{array}$ & $\begin{array}{l}\text { Rounded or sub- } \\
\text { cordate }\end{array}$ \\
\hline 6 & Inflorescence & $\begin{array}{l}\text { Peduncle un- } \\
\text { known }\end{array}$ & Peduncle unknown & $\begin{array}{l}\text { Peduncle very } \\
\text { short } 2-5 \mathrm{~mm} \\
\text { or sessile }\end{array}$ & $\begin{array}{l}\text { Peduncle un- } \\
\text { known }\end{array}$ & $\begin{array}{l}\text { Peduncle 4- } \\
\text { angled, drying } \\
\text { black }\end{array}$ \\
\hline 7 & Locality & $\begin{array}{l}\text { Sumatra, } \\
\text { Mount Malin- } \\
\text { tang }\end{array}$ & Java & Java & $\begin{array}{l}\text { Borneo, Mar- } \\
\text { tapura }\end{array}$ & $\begin{array}{l}\text { Aceh, North Su- } \\
\text { matra }\end{array}$ \\
\hline
\end{tabular}

narrowly cuneate, apex long acute to acuminate; petiole $10-13 \mathrm{~mm}$ long, slender or swollen, scaly, peeling off; midrib rounded below, pale brown when dry; lateral veins very faint on both the upper and lower surfaces $c a$. 30 pairs, $1-2 \mathrm{~cm}$ apart, at an angle of $60^{\circ}-70^{\circ}$, oil dots a few per $\mathrm{cm}^{2}$; intramarginal vein 1 , very faint $1-2 \mathrm{~mm}$ from margin. Inflorescence simple or paniculate to $5 \mathrm{~cm}$ long, terminal, up to 21 flowers per inflorescence. Rachis terete and 4-angled, drying dark brown. Flowers with short ultimate inflorescence axis, pseudostipe and hypanthial cup 8-15 mm long, trumpet-shaped to turbinate. Sepals 4 free, semiorbicular, $3.5 \mathrm{~mm}$ long ca. $4 \mathrm{~mm}$ wide. Petals semiorbicular $c a .5 .5 \mathrm{~mm}$ long and wide, a few gland dots. Stamens $c a .10 \mathrm{~mm}$ long. Style $c a .20$ $\mathrm{mm}$ long. Ovary 2-locular. Fruits campanulate (immature).

Distribution. Java. In Sumatra, Syzygium confusum is known only from Batam Island.

Notes. Koorders \& Valeton (1900) realised that Blume's specific epithet confusa could not be combined with Eugenia because it was pre-empted by E. confusa DC. (1828), so that he proposed the new combination E. doligophylla. This, however, is an orthographic variant of the earlier E. dolichophylla Kiaersk. (1893) as can be seen when Koorders himself corrected it (1912). It is not a misprint as was suggested by Henderson (1949: 50), as the spelling is consequently used throughout in the 1900 paper. This combination is therefore also a later homonym and illegitimate.

Gagnepain (1921) proposed the new name $E$. malayana for this species (Govaerts et al., 2008), which Turner (1997a, b) used in Syzygium, overlooking the fact that $S$. confusum was required, and that this combination had already been made by Bakhuizen van den Brink Jr. \& Koster (1963). Gagnepain's specimens (Dussaud s.n., Harmand 1314 and Thorel s.n.) and his description based on them actually refer to Syzygium megacarpum (Craib) Rathakr. \& N.C.Nair (Wuu Kuang Soh, $\mathrm{TCD}$, in litt.).

Unaware of Gagnepain's action Merrill (1951) proposed yet another name: Syzygium amshoffianum, which is superfluous.

3. SYZYGIUM BLUMEI (Steud.) Merr. \& L.M.Perry. - Fig. 3.

Eugenia angustifolia Blume, Flora 7(1): 291 (1824), [nom. illeg., non Eugenia angustifolia Lam., Encycl. 3: 203 (1789)]. - Myrtus 
hypericifolia Blume, Bijdr. Fl. Ned. Ind.: 1082 (1826) [nom. illeg., non Myrtus hypericifolia Salisb., Prodr. Stirp. Chap. Allerton: 354 (1796)]. Jambosa hypericifolia (Blume) DC., Prodr. [A. P. de Candolle] 3: 287 (1828), nom. illeg. Eugenia hypericifolia (Blume) Koord. \& Valeton, Meded. Lands Plantentuin 40, Bijdr. 6: 69 (1900) [nom. Illeg.] - Eugenia blumei Steudel, Nomencl. Bot. ed. 2. 1: 601 (1840). Syzygium blumei (Steudel) Merr. \& L.M.Perry, Mem. Amer. Acad. Arts 18: 164 (1939). - TYPE: INDONESIA, Jawa, Bogor. (Holotype L! HLB no. 898.203-344). labelled as Jambosa confusa, and preidentified/ annotated as Syzygium cf. confusum (Blume) Bakh.f. by Bakhuizen van den Brink f. \& van Steenis in April 1972.

Habit unknown. Twigs terete, glabrous, drying yellowish. Leaves sessile, glabrous, narrowly ovate, $6-19 \mathrm{~cm}$ long by $1.5-3 \mathrm{~cm}$ wide; leaf base rounded to subcordate, leaf apex acute to acuminate; major lateral veins 6-9 pairs, very faint on both surfaces; leaves drying greyish above and yellowish below. Inflorescence terminal and in leaf axil. Pedicel terminally solitary, 1 flower with shorter petals. Calyx 4 lobed, base attenuate. Fruit unknown.

Distribution. West Java, Mt. Salak.

Habitat \& Ecology. Tropical rain forest.

4. SYZYGIUM INSIGNE (Blume) Merr. \& L.M.Perry - Fig. 4.

Jambosa insignis Blume, Mus. Bot. Lugd.-Bat. 1: 100. 1849. Syzygium insigne (Blume) Merr. \& L.M. Perry, Mem. Acad. Arts \& Sci. 18: 163. 1939. Mem. Gray Herb. Harvard Univ. 4: 163. 1939; Masam., Enum. Phan. Born.: 530. 1942. Jambosa lancifolia Miq., Anal. Ind. 1: 17. 1850; Fl. Ned. Ind. 1, 1: 427. 1855, nom. superfl. -TYPE: INDONESIA, Borneo, Martapoera. Korthals s.n. (Holotype L! HLB no. 898.203347), accepted by Merrill (1921), Merrill \& Perry (1939), and Masamune (1942).

Tree, height and diameter unknown. Twigs 4angled. Leaves opposite, very shortly petiolate nearly two-ranked, narrowly ovate, leaf apex acute, base subcordate or almost rounded, 4-10 $\mathrm{cm}$ by $1-2.75 \mathrm{~cm}$, transverse veins confluent in the inframarginal nerve, coriaceous, shiny above, and often impressed with inconspicuous dots, paler below. Racemes $1-3$, terminal and solitary in the axils, short, few-flowered. Flowers showy, rather longly pedicellated, pink. Calyx about 2.5 $\mathrm{cm}$, tube of the calyx turbinate, widened above, the limb with sort rounded flaps of 6-8-fid, lobes unequal, the outermost shorter, deciduous.

\section{Distribution. Borneo.}

Notes. Not to be confused with Eugenia insignis Thwaites from Sri Lanka, a "true" Eugenia. Miquel (1850: 17) did not mention Eugenia insignis Blume, but described E. lancifolia as new based on the same material, so that the name is superfluous. Though he realised it in 1855 (p. 427), he still retained his own epithet. Merrill (1921: 429) regarded Jambosa insignis and J. lancifolia as distinct species, repeating Blume's suggestion that more than one collection would be involved. Merrill \& Perry (1939: 163) joined the two, but did not mention Jambosa lanceolata at all, probably because they were aware that this was a Sumatran species, whereas they were dealing with Bornean material.

5. Syzygium sipirokense Widodo \& Veldkamp spec. nov. - Fig. 5.

- TYPE: INDONESIA, Sumatra, Tapanuli Selatan, Cagar Alam Sipirok, Nagurguran. EA Widjaja 2012, 19 March 1983 (Holotype BO!).

Small tree or shrub. Twigs winged near the nodes. Leaves sessile, opposite, lanceolate, $10-15 \mathrm{~cm}$ by 3 $-5.5 \mathrm{~cm}$, leaves upper surface dark brown, lower surface brown when dry. Major lateral veins 10 14; leaf base rounded or cordate; leaf apex acuminate to apiculate; intramarginal veins one, $1-$ $2 \mathrm{~mm}$ from margin, channelled above, raised below. Inflorescence arises from the leaf axil, peduncle four-angled, slightly winged, slender, black when dry. Flower unknown. Fruit ovoid to oval, 8-12 mm long, 5-7 mm diameter, green-red.

Distribution. Aceh Province, Aceh Tenggara Regency. North Sumatra, Tapanuli Selatan, Cagar Alam Sipirok, Nagurguran.

Habitat \& Ecology. Primary forest $700 \mathrm{~m}$ alt.

Etymology. The epithet sipirokense came from one of the areas where this specimen was collected.

Conservation Status. This species is known from two locations, namely Sipirok Nature Reserve in North Sumatra and Ketambe Research Station in Aceh. The IUCN Assessment (IUCN, 2020) is categorized as Critically Endangered (CR). 


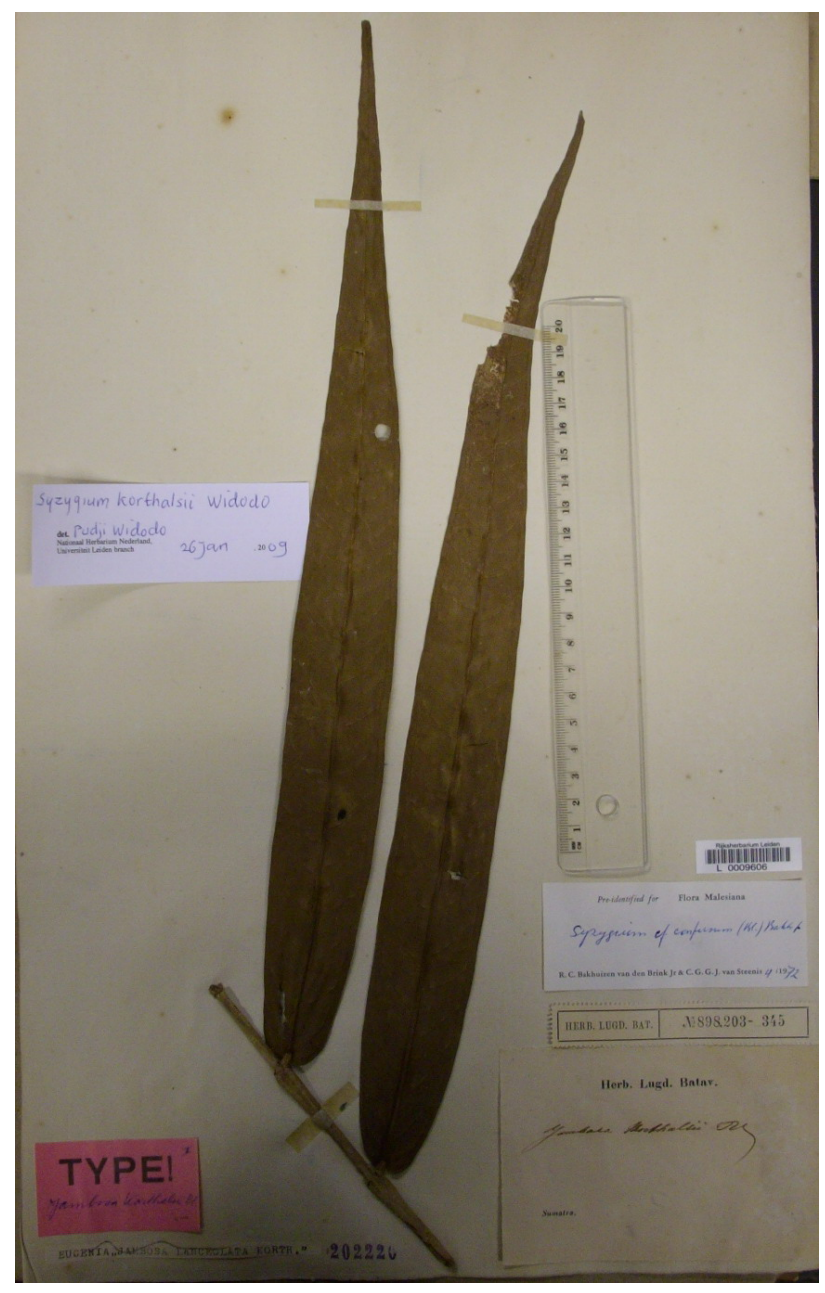

Fig. 1. Syzygium korthalsii. Leafy twig.

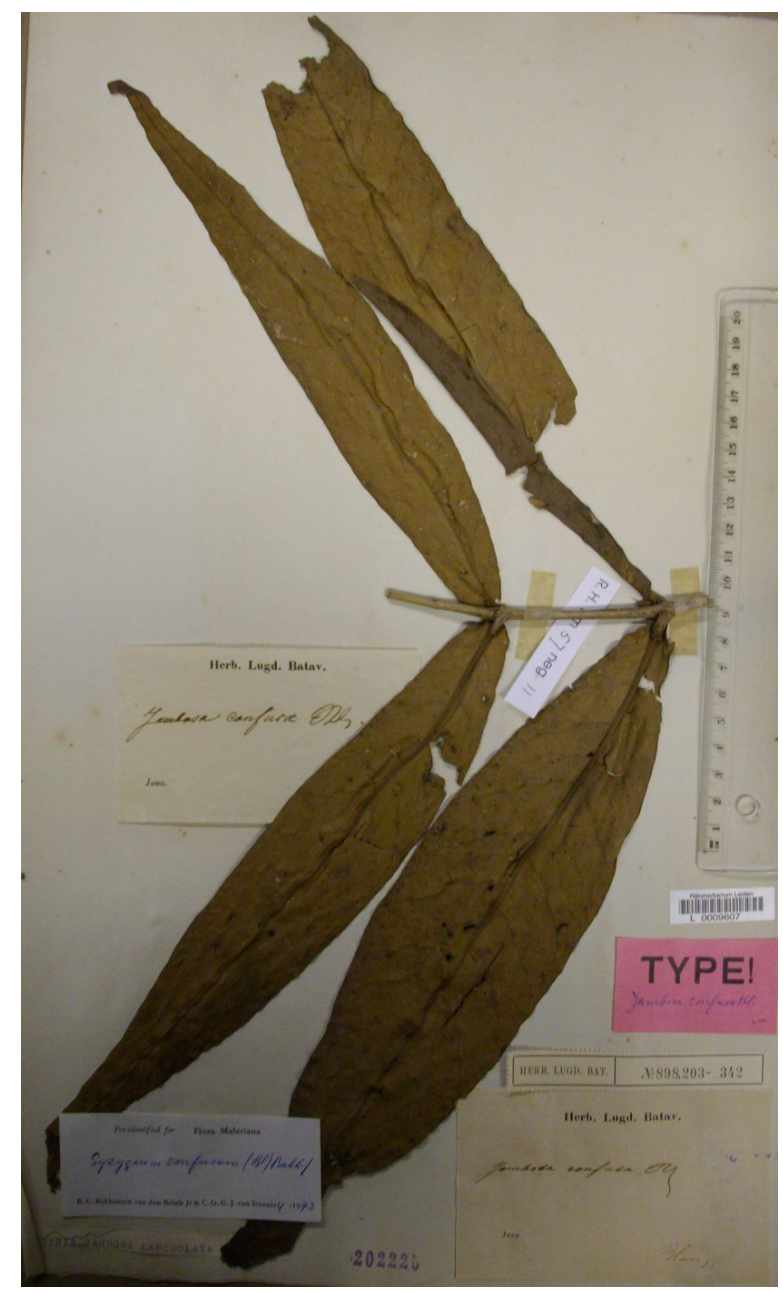

Fig. 2. Syzygium confusum. Leafy twig.
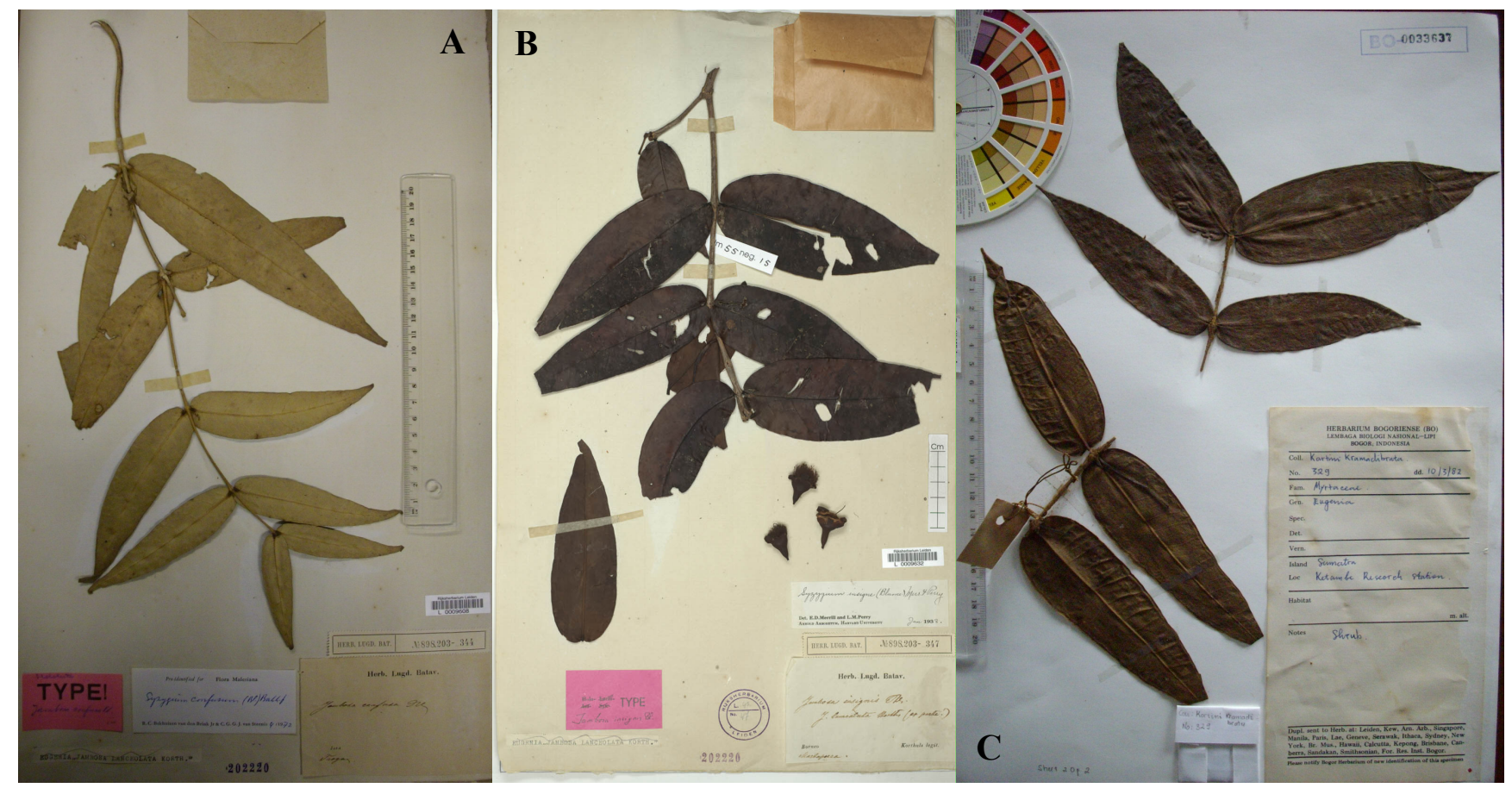

Fig. 3. A. Syzygium blumei. B. Syzygium insigne. C. Syzygium sipirokense Widodo \& Veldkamp spec. nov. 
Specimen Examined. Sumatra, Aceh, Ketambe Research Station. Kramadibrata K 329, K 333, 11 March 1982.

Notes. Syzygium sipirokense resembles S. blumei. However, the leaves of Syzygium sipirokense dry dark brown above and pale brown below, instead of drying greyish above and yellowish below as in S. blumei. Twigs of Syzygium sipirokense are 4winged, while the twigs of $S$. blumei are terete.

\section{ACKNOWLEDGEMENTS}

The first author has been supported by a grant from the Directorate General of Higher Education, the Republic of Indonesia. Acknowledgement is due to Prof. Dr. Alex Hartana and Prof. Dr. Tatik Chikmawati who have supervised the first author during his study and to Prof. Dr. Mien A. Rifai for improving the rewritten final manuscript. We would like to appreciate the Keepers of $\mathrm{L}$, $\mathrm{K}$, and BO for permission to observe the collections. Prof. Dr. Peter van Welzen is thanked for his assistance and service. Dr. Lyn Craven $(\dagger)$, CSIRO, Australia, is acknowledged for his advice. Prof. Dr. John Parnell, Trinity College Dublin is thanked for providing references. Dr. Rafael Govaerts, Royal Botanic Gardens Kew is appreciated for giving relevant information. Dr. Wuu Kuang Soh, Trinity College Dublin kindly commented on Gagnepain's new name. Grateful acknowledge-ment is due to Dr. Eve Lucas, Royal Botanic Garden Kew for her critical review of the manuscript.

\section{REFERENCES}

BAKHUIZEN VAN DEN BRINK Jr., R. C. \& KOSTER, J. T. 1963. Notes on the Flora of Java VIII. Myrtaceae. Blumea 12: 61.

BLUME, C. L. 1849. Ord. Myrtaceae. Subord. Myrteae. Museum botanicum LugdunoBatavum 1 (7): 100-101.

DE CANDOLlE, A. P. 1828. Prodromus Systematis Naturalis Regni Vegetabilis 3: 279. Treutel \& Würz, Paris.

GAGNEPAIN, F. 1921. Myrtaceae. In: LECOMTE, P. H. Flora of Indo-Chine 2: 838. Masson \& Cie, Paris.

GOVAERTS, R., SOBRAL, M., ASHTON, P., BARRIE, F., HOLST, B. K., LANDRUM, L. L., MATSUMOTO, K., MAZINE, F. F., LUGHADHA, E. N., PROENÇA, C., SOARES-SILVA, L. H., WILSON, P. G.,
LUCAS, E. 2008. World Checklist of Myrtaceae. Kew Publishing. Royal Botanic Gardens, Kew.

HENDERSON, M. R. 1949. The genus Eugenia (Myrtaceae) in Malaya. Gardens' Bulletin Singapore 12: 50-51.

KOORDERS, S. H. 1912. Exkursionsflora von Java 2. Fischer, Jena.

KOORDERS, S. H. \& VALETON, T. 1900. Bijdrage no. 6 tot de kennis der boomsoorten op Java. Mededeelingen uit's Lands Plantentuin 40: 78-79.

KORTHALS, P. W. 1846. Bijdrage tot de kennis der Myrtaceae. Nederlandsch kruidkundig archief 1: 199.

MASAMUNE, G. 1942. Enumeratio phanerogamarum bornearum: 530. Government of Taiwan, Taipei.

MERRILL, E. D. 1921. A bibliographic enumeration of Bornean plants. Journal of the Straits branch of the Royal Asiatic Society Special Number: 428-429.

MERRILL, E. D. 1951 (“1950”). Readjustments in the nomenclature of Philippine Eugenia species. Philippine Journal of Science 79: 366.

MERRILL, E. D. \& PERRY, L. M. 1939. The myrtaceous genus Syzygium Gaertner in Borneo. Memorial Academic Arts \& Science 18: 163. $\equiv$ Memorial Gray Herbarium of Harvard University 4: 163.

MIQUEL, F. A. W. 1850. Stirpes quaedam borneenses. Analecta Botanica Indica 1: 17, 27.

MIQUEL, F. A. W. 1855. Flora van Nederlandsch Indië 1(1): 427. C.G. van der Post, Amsterdam, C. van der Post Jr., Utrecht.

RIFAI, M. A. 1976. Sendi-Sendi Taksonomi Tumbuhan. Herbarium Bogoriense, Bogor.

TURLAND, N. J., WIERSEMA, J. H., BARRIE, F. R., GREUTER, W., HAWKSWORTH, D. L., HERENDEEN, P. S., KNAPP, S., KUSBER, W. H., LI, D. Z., MARHOLD, K., MAY, T. W., MCNEILL, J., MONRO, A. M., PRADO, J., PRICE, M. J. \& SMITH, G. F. (Eds.). 2018. International Code of Nomenclature for algae, fungi, and plants (Shenzhen Code) adopted by the Nineteenth International Botanical Congress Shenzhen, China, July 2017. Regnum Vegetabile 159. Glashütten: Koeltz Botanical Books. DOI https://doi.org/10.12705/ Code.2018.

TURNER, I. M. 1997a. (16 Jul 1997; “1995”). A catalogue of vascular plants of Malaya. Gardens' Bulletin Singapore 47: 378, 384. 
TURNER, I. M. 1997b. (Aug 1997; “1996”). What should the kelat trees of Malaya be called? Journal of the Singapore National Academy of Science 22-24: 21.

VOGEL, E. DE (Editor). 1987. Manual of Herbarium Taxonomy: Theory and Practice. UNESCO Southeast Asia Regional Office, Jakarta.
WIDODO, P. 2011. Syzygium of Sumatra: The Free Petalled Species. LAP Lambert Academic Publishing GmbH \& Co. Saarbrücken, Germany.

WIDODO, P. 2012. New nomenclature in Syzygium (Myrtaceae) from Indonesia and its vicinities. Reinwardtia 13 (3): 235-240.

WIGHT, R. \& WALKER-ARNOTT, G. A. 1834. Prodromus Florae Peninsulae Indiae Orientalis 1. Parbury, Allen \& Co. 
